\title{
Identification and Phylogenetic Analysis of Bacterial Isolates from Litopenaeus vannamei Shrimp Culture System and Gut Environment Based on 16SrRNA Gene Sequence Data
}

\author{
TUBAGUS HAERU RAHAYU ${ }^{1,2^{*}}$, INDRAWATI GANDJAR ${ }^{1}$, ETTY RIANI ${ }^{3}$, \\ IIN SITI DJUNAIDAH ${ }^{4}$, AND WELLYZAR SJAMSURIDZAL ${ }^{1}$
}

\begin{abstract}
${ }^{I}$ Department of Biology, Faculty of Mathematics and Natural Sciences, Universitas Indonesia, Depok 16424, Indonesia; ${ }^{2}$ Department of Aquaculture, Sekolah Tinggi Perikanan Jakarta; Jalan AUP Pasar Minggu, Jakarta 12520, Indonesia; ${ }^{3}$ Faculty of Fisheries and Marine Science, Institut Pertanian Bogor, Kampus Darmaga, Bogor 16680, Indonesia; ${ }^{4}$ Agency for Human Resources Development of Marine and Fisheries, Departemen Kelautan dan Perikanan, Jalan MT. Haryono Kav. 52-53, Jakarta 12770, Indonesia
\end{abstract}

\begin{abstract}
Selected bacterial isolates from a Litopenaeus vannamei shrimp culture system and gut environment were assessed using $16 \mathrm{~S}$ rRNA gene sequencing method to identify their identity and to construct their phylogenetic relationship. In a preliminary study, a total of 19 isolates were selected as probiotics. These isolates were prepared using freeze and heat-shock method to obtain the DNA template. PCR amplification of $16 \mathrm{~S}$ ribosomal RNA gene of isolates was carried out using bacterial universal primers $9 \mathrm{~F}$ and 1510R and was sequenced using an automated DNA sequencer. These gene sequences were compared with other gene sequences in the GenBank database (NCBI) using a BLAST search to find closely related sequences. Alignment of these sequences with sequences available from GenBank database was carried out to construct a phylogenetic tree for these bacteria. Most of the isolates obtained, i.e. 17 out of the 19 isolates, belonged to different species of Bacillus, sharing 95 to $99 \%$ 16S ribosomal RNA identity with the respective type-strain, whereas the remaining 2 isolates belonged to Micrococcus sp. and Micrococcus luteus, with 97 to $99 \%$ 16S rRNA homology, consecutively.
\end{abstract}

Key words: Bacillus, Micrococcus, PCR amplification of 16S rRNA gene, phylogeny

The growing economic importance of the aquaculture industry worldwide and the need to find a new approach for a probiotic method has led to increasing interest in rapid and reliable methods for detection and identification of bacteria (Nilsson and Strom 2002). Recently, nucleic acid-based assays have been studied intensively. One of methods being developed is that of $16 \mathrm{~S}$ ribosomal RNA genes sequencing. These assays are generally considered to be more accurate, more sensitive, inexpensive and more rapid to perform than those of more conventional variety, such as morphological, biochemical/physiological and serological assays, which led to various results of species resemblance in physiology and susceptibility to environmental exchanges (Macrae 2000).

Broad-range PCR amplification of 16S rDNA with universal bacterial primers and subsequent sequence analysis of cloned products is a widely used method in molecular biology. The method can be used for identification of microorganism identity to the genus or species level (Tiirola et al.2002) and construct phylogenetic analysis which plays on important role in taxonomic positioning. It can be undertaken by comparing the gene sequences with other bacteria sequences in the GenBank database using basic local alignment search tool (BLAST) search and continue with method of neighbor-joining to construct a phylogenetic tree (Saitou and Nei 1987; Holmes 2003).

In this paper, we identified the selected bacterial isolates from $L$. vannamei culture system and gut environment using the $16 \mathrm{~S}$ ribosomal RNA gene sequence and constructed and analyzed the phylogenetic trees using the program Clustal X.

Corresponding author, Phone/Fax: +62-21-7890962,

E-mail: haeru_tb@yahoo.com
It is important to understand that genetic diversity of selected isolates of probiotic bacteria and their taxonomic position provides basic information for developing disease control strategies in the shrimp culture industry.

\section{MATERIALS AND METHODS}

Sampling of Bacteria and Isolation. Bacterial isolates were obtained from the water, sediments and shrimp's gut using healthy wild shrimps ( $15 \pm 1 \mathrm{~g})$ collected from four districts, i.e., Pandeglang, Serang, Tangerang and Karawang. Sampling stations were determined randomly with 5 to 7 spots per pond. Substrates were taken from 3 substrates, i.e. pond water, mud and shrimp' gut following the procedures of Hjelm et al. (2004). Water aliquots of $500 \mathrm{~mL}$ and mud aliquot of 50 to100 $\mathrm{g}$ were taken using sterile plastic bags and stored in refrigerator at $4{ }^{\circ} \mathrm{C}$. Samples from shrimp' guts were conducted by taking living shrimps to the laboratorium using closed transportation with air and water at a ratio 3:1.

Sample of 5\% of obtained material were taken and then isolated and enriched on TSB medium with $2 \% \mathrm{NaCl}$ and incubated for $24 \mathrm{~h}$ at $30^{\circ} \mathrm{C}$ before streaking bacteria on marine agar. Samples from mud of 50\% (w/v) were diluted using sterile distilled water, whereas samples from shrimp's guts were taken by gut-scraping.

All subsequent isolates were streaked on marine agar and incubated for $24 \mathrm{~h}$ at $30^{\circ} \mathrm{C}$. Representative colonies were selected based on phenotype, Gram staining and acidity of the medium. The selected isolates were cultured on slashmarine-agar and stored at $4-10{ }^{\circ} \mathrm{C}$ after separation into three groups, i.e. original culture, stock culture and working culture.

Development of Pure Cultures of Isolates. Nineteen selected isolates from the slash-agar stock were streaked in 
duplicate on the respective media (marine agar, DIFCO, 55.1 $\mathrm{g} \cdot \mathrm{l}^{-1}$ ) plates and incubated at $30^{\circ} \mathrm{C}$ for $48 \mathrm{~h}$. The isolates were then stored in a refrigerator for short periods until further use.

Preliminary Characterization of Isolated Bacteria. Characterization of isolates was done following the method of Akhtar et al. (2008). Colonies on respective media plates were examined using the light microscope and their characteristics i.e. color, form, elevation and margin of colonies were recorded. Isolates were also characterized on the basis of Gram staining.

DNA Template Preparation. DNA templates were prepared by using the freeze and heat-shock method (Sjamsuridzal and Oetari 2003). Incubated isolates (48 h) were taken using sterile microtips and put into $1.5 \mathrm{~mL}$ microtube containing $500 \mu \mathrm{L}$ of nuclease-free water. The cell suspension was vortexed for $1 \mathrm{~min}$ and then frozen for $24 \mathrm{~h}$. The suspension was then boiled using a water bath $\left(>95^{\circ} \mathrm{C}\right)$ for $20 \mathrm{~min}$. The cells suspension was centrifuged at $13000 \mathrm{rpm}$ for $15 \mathrm{~min}$. The supernatant containing the DNA was stored in a refrigerator until further use.

Phylogenetic Analysis of Isolates. Polymerase chain reaction amplification of $16 \mathrm{~S}$ ribosomal RNA of isolates were carried out using following primers and set of conditions: forward primer (9F; 5'-GAGTTTGATCCTGGCTCAG-3' and reverse primer (1510R; 5' GGCTACCTTGTTACGA-3') (Nilsson and Strom 2002). Each vial contained $1.25 \mu \mathrm{L}$ of each primer, $15 \mu \mathrm{L}$ RTG suspended with nuclease free water and $7.5 \mu \mathrm{L}$ DNA template in a total $25 \mu \mathrm{L}$ reaction volume. The reaction mixture was heated for $3 \mathrm{~min}$ at $95^{\circ} \mathrm{C}$ and then amplification was carried out in 35 cycles. Each cycle was comprised of 30 sec at $95^{\circ} \mathrm{C}, 15 \mathrm{sec}$ at $55^{\circ} \mathrm{C}$ and $1 \mathrm{~min}$ at $72{ }^{\circ} \mathrm{C}$. The final extension was for $5 \mathrm{~min}$ at $72^{\circ} \mathrm{C}$ followed by storage at $25^{\circ} \mathrm{C}$. The PCR product was purified using sodium acetate/ethanol precipitation to remove excess primers and free nucleotides.

The next step was cycle-sequencing reaction, in which a similar process to amplification of $16 \mathrm{~S}$ ribosomal RNA was performed. Each vial contained $1 \mu \mathrm{L}$ Big Dye Terminator Ready Reaction Mix V.3.1, 0.5 $\mu \mathrm{L}$ primer 9F, 7.0 $\mu \mathrm{L}$ sequence buffer, $0.5 \mu \mathrm{L}$ nuclease free water and $1 \mu \mathrm{LDNA}$ template in a total of $10 \mu \mathrm{L}$ reaction volume. The reaction mixture was heated for $1 \mathrm{~min}$ at $96^{\circ} \mathrm{C}$ and then amplification was carried out over 30 cycles. Each cycle was comprised of $10 \mathrm{sec}$ at $96{ }^{\circ} \mathrm{C}, 5 \mathrm{sec}$ at $55^{\circ} \mathrm{C}$ and $90 \mathrm{sec}$ at $60{ }^{\circ} \mathrm{C}$. The final step was storage at $25^{\circ} \mathrm{C}$. The PCR product was re-purified using sodium acetate/ethanol precipitation to remove excess dyeterminators, followed by denaturation using $15 \mu \mathrm{L}$ Hi-DI Formamide and heat denaturation at $95^{\circ} \mathrm{C}$ for $5 \mathrm{~min}$ and then immediately transferred on ice.

Amplified 16S ribosomal RNA fragments of about $1500 \mathrm{bp}$ size were obtained from each isolate and were partially sequenced (around $500 \mathrm{bp}$ ) using an automated DNA sequencer (ABI 310 PRISM), following the procedure given by the manufacturer. The gene sequences were compared with others in the GenBank databases using the NCBI BLAST (www.ncbi.nlm.nih.gov). Gene sequences of 16S ribosomal RNA of selected organisms were obtained from GenBank and aligned with gene sequence of our isolates using a multiple sequence alignment program CLUSTAL X software (Thompson 1997). The aligned sequences were used to construct a distance matrix, after the generation of 100 bootstrap sets, which was subsequently used to construct a phylogenetic tree using the neighbor-joining method (Holmes 2003).

\section{RESULTS}

Colony and Cell Morphologies of Isolates. Nineteen isolates of selected putative probiotic bacteria were examined for studies on the basis of the colony color and bacterial morphology (Table 1). Colony pigmentation of the isolates included white, light pink, pink-orange, light yellow, yellow and pinkish red. These colonies were dominated by circular forms and only 4 isolates had circular-tending to a irregular form. Colony elevation was convex in all cases. All isolates had entire margins and gave Gram positive staining.

PCR Amplification of 16S rRNA Genes. Electrophoretic visualization of amplified 16S rRNA genes from nineteen selected probiotics using primer $9 \mathrm{~F}$ and $1510 \mathrm{R}$ is shown in

Table 1 Some characteristics of different isolates of selected putative probiotic bacteria

\begin{tabular}{|c|c|c|c|c|c|c|c|}
\hline \multirow{2}{*}{ Isolates code } & \multirow{2}{*}{ Substrate } & \multicolumn{4}{|c|}{ Macroscopic observation of colony } & \multirow[b]{2}{*}{ Elevation } & \multirow{2}{*}{ Gram staining } \\
\hline & & Color & Surface & Forms & Margins & & \\
\hline $\mathrm{S}_{18}$ & water & White & Glossy & Circular & Entire & Convex & Positive \\
\hline $\mathrm{T}_{1}$ & water & White & Glossy & Circular & Entire & Convex & Positive \\
\hline $\mathrm{T}_{17}$ & gut & White & Glossy & Circular & Entire & Convex & Positive \\
\hline $\mathrm{T}_{28}$ & gut & White & Glossy & Circular & Entire & Convex & Positive \\
\hline $\mathrm{P}_{18}$ & gut & White & Glossy & Circular & Entire & Convex & Positive \\
\hline $\mathrm{T}_{9}$ & gut & Light Pink & Glossy & Circular & Entire & Convex & Positive \\
\hline $\mathrm{P}_{43}$ & water & Light Pink & Glossy & Circular & Entire & Convex & Positive \\
\hline $\mathrm{T}_{21}$ & gut & Pink Orange & Glossy & Circular & Entire & Convex & Positive \\
\hline $\mathrm{T}_{26}$ & gut & Pink Orange & Glossy & Circular & Entire & Convex & Positive \\
\hline $\mathrm{K}_{48}$ & sediment & Pink Orange & Glossy & Circular tend to Irregular & Entire & Convex & Positive \\
\hline $\mathrm{P}_{10}$ & sediment & Pink Orange & Glossy & Circular tend to Irregular & Entire & Convex & Positive \\
\hline $\mathrm{P}_{16}$ & water & Pink Orange & Glossy & Circular tend to Irregular & Entire & Convex & Positive \\
\hline $\mathrm{P}_{11}$ & water & Pink Orange & Glossy & Circular tend to Irregular & Entire & Convex & Positive \\
\hline $\mathrm{S}_{9}$ & gut & Light yellow & Glossy & Circular & Entire & Convex & Positive \\
\hline $\mathrm{T}_{23}$ & gut & Yellow & Glossy & Circular & Entire & Convex & Positive \\
\hline $\mathrm{S}_{23}$ & sediment & Pinkish red & Glossy & Circular & Entire & Convex & Positive \\
\hline $\mathrm{T}_{18}$ & water & Pinkish red & Glossy & Circular & Entire & Convex & Positive \\
\hline $\mathrm{K}_{52}$ & water & Pinkish Red & Glossy & Circular & Entire & Convex & Positive \\
\hline $\mathrm{P}_{7}$ & sediment & Pinkish Red & Glossy & Circular & Entire & Convex & Positive \\
\hline
\end{tabular}

S18 until P1 shown the isolates code of selected indigenous bacteria 
Fig 1. The characteristic bacterial $16 \mathrm{~S}$ gene amplicon of about 1500 bp was clearly visible in all cases.

Identity of Isolates Based on 16S-rRNA-Sequence Method. Nucleotides BLAST search of partial sequences (500 bp) of the $16 \mathrm{~S}$ rRNA for various isolates showed that most of the isolates had variable percentage identity with Bacillus (95-99\%), whereas the remainder, i.e. isolate $\mathrm{S}_{23}$ and $\mathrm{S}_{9}$, had $97 \%$ and $99 \%$ homology to Micrococcus sp. and Micrococcus luteus, respectively (Table 2).

Construction of Phylogenetic Tree. A phylogenetic tree was developed by aligning $16 \mathrm{~S}$ rRNA sequences of different bacteria taken from GenBank, NCBI and sequences of the isolates from this study (Fig 2).

Isolate $\mathrm{S}_{9}$ was related to Micrococcus luteus clone B14. It shared $99 \%$ similarity in its $16 \mathrm{~S}$ ribosomal RNA sequence, whereas isolate $\mathrm{T}_{23}$ was related to Micrococcus sp. Mali2 and Kocuria sp. with $97 \%$ similarity. Based on the morphology of colony (Table 1), both isolates had similarity in patters of surface, form, margin, elevation and Gram staining i.e., glossy, circular, entire, convex and Gram positive, consecutively. The defining feature of both isolates was that isolate $\mathrm{S}_{9}$ had a light yellow color, whereas $\mathrm{T}_{23}$ was yellow.

Meanwhile, the cluster of the Bacillus group was divided into six clusters. The first cluster consisted of isolates $\mathrm{P}_{18}$, $\mathrm{S}_{18}, \mathrm{~T}_{28}, \mathrm{~T}_{1}$ and $\mathrm{T}_{17}$, which were closely related to Bacillus pumilus (DURCK14, S6-05, AU39 and NUC-F) and Bacillus antrachis (me-12), with similarity of 98, 98, 99, 99, 95\%, consecutively, and bootstrap value $99.9 \%$. The second cluster consisted of two isolates, i.e. $\mathrm{T}_{21}$ and $\mathrm{T}_{26}$. Both isolates related to Bacillus sp. WRB-4, with similarity 95 and $97 \%$ consecutively with bootstrap value of $100 \%$. The third cluster was divided into two sub-clusters. The first was isolate $\mathrm{P}_{7}$, which was related to Bacillus sp. Mali10 with similarity of both $97 \%$ while the second sub-cluster was isolates $\mathrm{S}_{23}$ and $\mathrm{K}_{52}$, which were close to Bacillus sp. By231Ydz-fq with a similarity of $96-97 \%$. The fourth cluster was isolate $\mathrm{T}_{18}$. This was close to Bacillus sp. K38T with a $99 \%$ similarity. The fifth cluster was represented by $\mathrm{T}_{9}$ and $\mathrm{P}_{43}$ which were related to Bacillus subtilis S8-04 and Bacillus megaterium TK1 with a similarity of 96 and $98 \%$ consecutively. The sixth cluster was again divided into sub-clusters. The first sub-cluster consisted of isolate $\mathrm{P}_{10}$ with a $99 \%$ similarity and related to Bacillus flexus LLH. The second sub-cluster was represented by isolates $\mathrm{K}_{48}, \mathrm{P}_{16}$ and $\mathrm{P}_{11}$, and related to Bacillus flexus GS11 and Bacillus sp. Bsi20565 with similarities of 95, 97, 98 and bootstrap values higher than $60 \%$.

\section{DISCUSSION}

This is a preliminary study on the characteristics of nineteen isolated colonies. Colonies were grown on agar media and were visible after $12 \mathrm{~h}$ incubation at $30^{\circ} \mathrm{C}$. This is due to the presence of sufficient nutrient, appropriateness of the agar used and appropriateness of the culture period. Marine agar (DIFCO; $55.1 \mathrm{~g} \mathrm{l}^{-1}$ ) is a specific agar for heterotrophic marine bacteria. It contains $2 \%(\mathrm{w} / \mathrm{v}) \mathrm{NaCl}$. Such conditions were appropriated for isolates which were obtained from shrimp ponds with a salinity of about $25 \mathrm{ppt}$. Thus the physiological activity from the bacteria was not disrupted. The $48 \mathrm{~h}$-incubation-period was adequate enough for bacterial growth. Our study showed the colonies grew

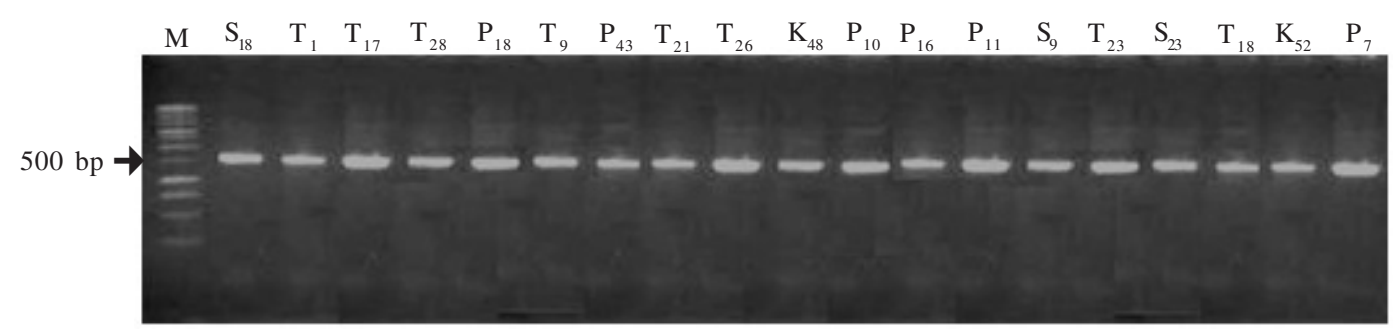

Fig 1 Visualization of amplification of 16S rRNA genes from 19 selected using primer 9F and 1510R. M, Marker; bp, base pair; S18 until P1 shown the code of selected indigenous bacteria isolates.

Table 2. Nearest relative of various selected isolates of probiotic bacteria

\begin{tabular}{|c|c|c|c|c|}
\hline Isolate & Substrate & Nearest relative & Accession Number & Homology $(\%)$ \\
\hline $\mathrm{S}_{18}$ & water & Bacillus pumilus isolate NUC-F & DQ833752 & 98 \\
\hline $\mathrm{T}_{1}$ & water & Bacillus pumilus strain S6-05 & EU624429 & 99 \\
\hline $\mathrm{T}_{17}$ & gut & Bacillus pumilus strain AU39 & EF032679 & 95 \\
\hline $\mathrm{T}_{28}$ & gut & Bacillus pumilus strain DURCK14 & AM778191 & 99 \\
\hline $\mathrm{P}_{18}$ & gut & Bacillus pumilus isolate EGU275 & EF633222 & 98 \\
\hline $\mathrm{T}_{9}$ & gut & Bacillus subtilis strain S8-04 & EU620412 & 96 \\
\hline $\mathrm{P}_{43}$ & water & Bacillus megaterium strain TK1 & EU586034 & 98 \\
\hline $\mathrm{T}_{21}$ & gut & Bacillus sp. WRB-4 & EF636891 & 95 \\
\hline $\mathrm{T}_{26}$ & gut & Bacillus sp. WRB-4 & EF636891 & 97 \\
\hline $\mathrm{K}_{48}^{20}$ & sediment & Bacillus flexus strain GS11 & DQ365587 & 95 \\
\hline $\mathrm{P}_{10}$ & sediment & Bacillus flexus ISOLAT LLH & DQ333292 & 99 \\
\hline $\mathrm{P}_{16}$ & water & Bacillus flexus strain GS11 & DQ365587 & 97 \\
\hline $\mathrm{P}_{11}$ & water & Bacillus sp. BSi20565 & EU330341 & 98 \\
\hline $\mathrm{S}_{9}$ & gut & Micrococcus luteus clone B14 & EU196531 & 99 \\
\hline $\mathrm{T}_{23}$ & gut & Micrococcus sp. "Mali2" & AY211096 & 97 \\
\hline $\mathrm{S}_{23}$ & sediment & Bacillus sp. By $231 \mathrm{Ydz}-\mathrm{fq}$ & EU070372 & 96 \\
\hline $\mathrm{T}_{18}$ & water & Bacillus sp. K38T & AM983525 & 99 \\
\hline $\mathrm{K}_{52}$ & water & Bacillus sp. 'Mali10' & AY211104 & 97 \\
\hline $\mathrm{P}_{7}$ & sediment & Bacillus sp. 'Mali10' & AY211104 & 97 \\
\hline
\end{tabular}

S18 until P1 shown the isolates code of selected indigenous bacteria 


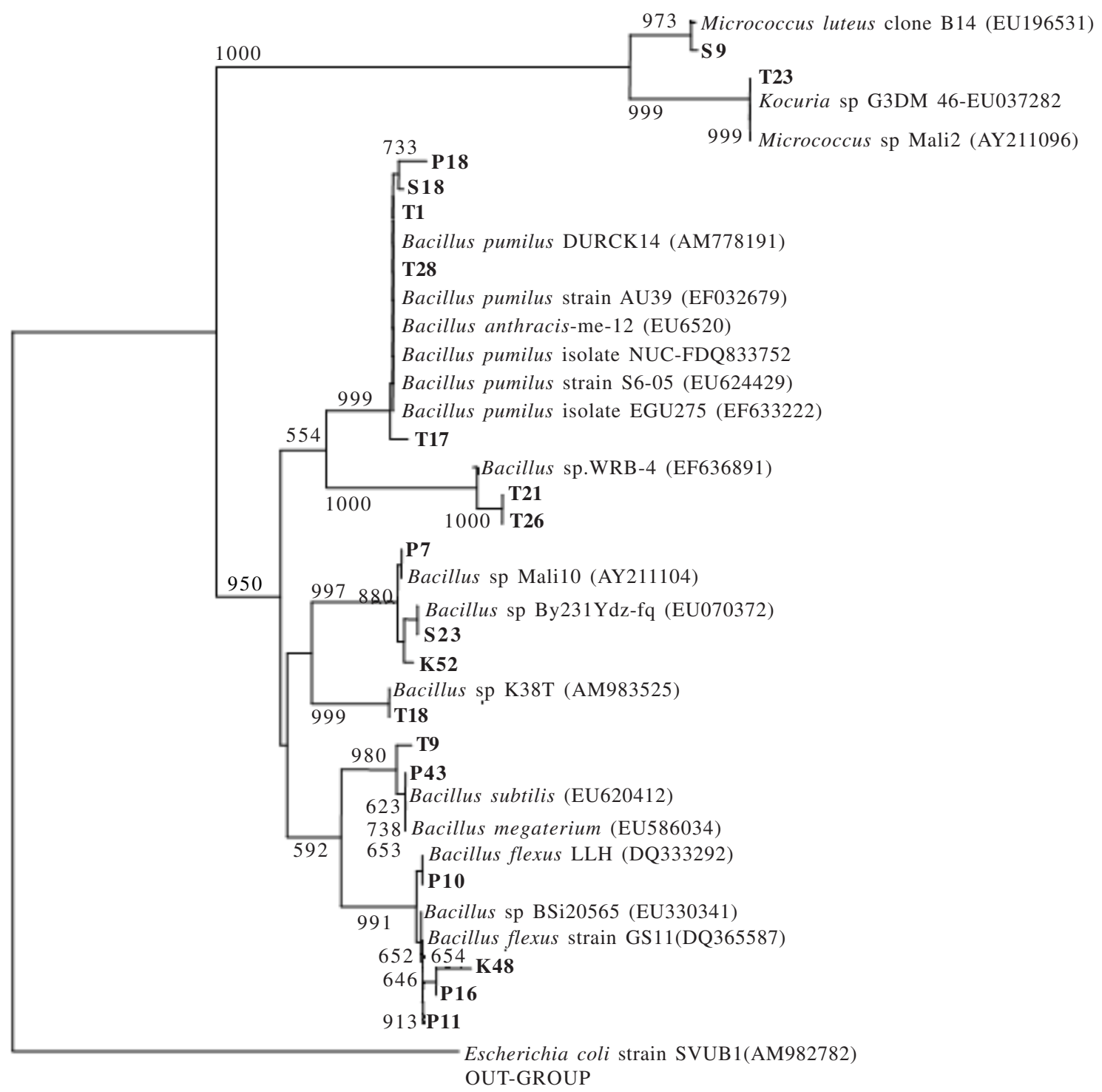

Fig 2 The inferred relationship based on partial 16S ribosomal RNA sequence, of selected putative probiotic bacteria (boldface) to other bacteria. The tree was rooted with Escherichia coli as an out-group. Scale bar represents the number of inferred nucleotide substitution per site. Bootstrap values (1000 replicates) are shown at the nodes.

well, with the typical color of bacteria. The results were in line with Akhtar et al. (2008), in that the growth of bacteria will also be determined by the period of incubation by giving enough time to reach the optimum stage.

On a molecular basis, all selected isolates belonged to the Gram positive group. Most of the isolates (17 isolates) were bacilli (89.7\%), with the remaining two isolates (10.53\%) being Micrococci (Table 1). It indicated that bacteria belonging to Bacilli group were more prevalent in healthy L. vannamei shrimp ponds. This finding was in line with those of Verschuere et al. (2000), Balcázar et al. (2006) and Geovanny et al. (2007) in which several bacteria were identified and can be considered as probiotic bacteria in aquaculture such as: Bacillus, Vibrio, Pseudomonas, Micrococcus, Bacteroides and Clostridium.

Gram negative bacteria were not found in the 19 culture isolates, after identification based on the sequence of $16 \mathrm{~S}$ ribosomal RNA. It was probably due to the fact Gram negative bacteria which were successful obtained during sampling of bacteria and isolation were not showing the characteristics of probiotic bacteria i.e. do not improve shrimps' survival rate during challenge test (Rengpipat et al. 2000).

Isolates related to Bacilli were represented by Bacillus sp. (isolates code: $\mathrm{T}_{21}, \mathrm{~T}_{26}, \mathrm{~T}_{18}, \mathrm{~K}_{52}, \mathrm{P}_{7}, \mathrm{P}_{11}$ and $\mathrm{S}_{23}$ ), B. pumilus (isolates code: $\mathrm{S}_{18}, \mathrm{~T}_{1}, \mathrm{~T}_{17}, \mathrm{~T}_{28}$ and $\mathrm{P}_{18}$ ), B. subtilis (isolate code: $\mathrm{T}_{9}$ ), $B$. megaterium (isolate code: $\mathrm{P}_{43}$ ), and $B$. flexus (isolates codes: $\mathrm{K}_{48}, \mathrm{P}_{10}$ and $\mathrm{P}_{16}$ ). Meanwhile, Micrococcus, was represented by Micrococcus sp. (isolate code: $\mathrm{T}_{23}$ ) and M. luteus (isolate code: $\mathrm{S}_{9}$ ). As the major species found, the dominance of Bacilli can be comprehended since they have a wide range of diversity in physiological ability with respect to heat, acidity and salinity tolerance. bacilli can be found in water, soil and the digestive tracts of several organisms, including shrimps (L. vannamei) (Rengpipat et al. 2000).

Although the genus Micrococcus has not a wide range of tolerance compared to Bacillus, it is however considered 
as a halotolerant group. Micrococcus can grow at 5\% (w/v) $\mathrm{NaCl}$, and manage to survive in the digestive tract as well. Geovany et al. (2007) reported that M. luteus was the major component of the population of the gut of Rainbow Trout (Oncorhynchus mykiss).

Phylogenetic analysis indicated that nineteen strains isolated from selected local probiotic bacteria can be identified as Gram positive bacteria of the Bacillus and Micrococcus species (Fig 2). When the type of Escherichia coli used for an out-group, it was clearly seen that the distribution of the nineteen of the isolates fell into two big clusters, i.e. Bacillus cluster and Micrococcus cluster. One was composed of seventeen Bacillus genera consisted of isolate $\mathrm{P}_{18}, \mathrm{~S}_{18}, \mathrm{~T}_{28}$, $\mathrm{T}_{1}, \mathrm{~T}_{17}, \mathrm{~T}_{21}, \mathrm{~T}_{26}, \mathrm{P}_{7}, \mathrm{~S}_{23}, \mathrm{~K}_{52}, \mathrm{~T}_{18}, \mathrm{~T}_{9}, \mathrm{P}_{43}, \mathrm{P}_{10}, \mathrm{~K}_{48}, \mathrm{P}_{16}$ and $\mathrm{P}_{11}$, indicated $95 \%$ in bootstrap value. The other was composed of two micrococcal strains, $\mathrm{S}_{9}$ and $\mathrm{T}_{23}$, indicated $100 \%$ in bootstrap value. The higher bootstrap value $(\geq 95 \%)$ indicated that both groups were clearly distinct (Meerak et al. 2007).

Based on the findings above, it may be concluded that the 19 isolates of bacteria can be used as probiotic bacteria and are useful for developing shrimp culture systems. Bacillus and Micrococcus are frequently used in shrimp aquaculture to improve the health status toward disease outbreaks through diet or giving out into water culture (Gatesoupe 1999; Verschuere et al. 2000; Balcázar et al. 2006).

\section{ACKNOWLEDGEMENT}

This research was supported partly by a Local Graduate Scholarship, awarded by the Ministry of Marine Affairs and Fisheries, and partly by the Research and Development for Public Affairs Unit of Sekolah Tinggi Perikanan.

\section{REFERENCES}

Akhtar N, Ghauri MA, Iqbal A, Anwar MA, Akhtar K. 2008. Biodiversities and phylogenetic analysis of culturable bacteria indigenous to Khewra salt mine of Pakistan and their industrial importance. Braz J Microbiol 39:143-50.

Balcázar JL, Blas I de, Zarzuela IR, Cunningham D, Vendrell D, Múszquiz JL. 2006. The role of probiotics in aquaculture. Vet Microbiol 114:173-86.

Hjelm M, Bergh $\varnothing$, Riaza A, Nielse J, Melchiorsen J, Jensen S, Duncan H, Ahrens P, Birkbeck H, Gram L. 2004. Selection and identification of autochthonous potential probiotic bacteria from Turbot Larvae (Scopthalmus maximus) rearing units. Syst Appl Microbial 27:360-71.

Gatesoupe FJ. 1999. The use of probiotics in aquaculture. A review. Aquaculture 180:147-65.

Geovany GR, Luis BJ, Shen MA. 2007. Probiotics as control agents in aquaculture. A review. J Ocean Univ China 6:76-9.

Holmes S. 2003. Bootstrapping phylogenetic trees: theory and methods. Stat Sci 18:241-55.

Macrae A. 2000. The use of $16 \mathrm{~S}$ rDNA methods in soil microbial ecology. Braz J Microbiol 31:77-82.

Meerak JHL, Watanabe Y, Miyashita M, Sato H, Nakagawa Y, Tahara Y. 2007. Phylogeny of $\gamma$-polyglutamic acid-producing Bacillus strains isolated from fermented soybean foods manufactured in Asian countries. J Gen Appl Microbiol 53:315-23.

Nilsson WB, Strom M S. 2002. Detection and identification of bacterial pathogens of fish in kidney tissue using terminal restriction fragment length polymorphism (T-RFLP) analysis of 16S RNA genes. Dis Aqua Org 48:175-85.

Rengpipat S, Rukpratanporn S, Piyatiratitivorakul S, Menasaveta P. 2000. Immunity enhancement in black tiger shrimp (Penaeus monodon) by a probiont bacterium (Bacillus S11). Aquaculture 191:271-88.

Saitou N, Nei M. 1987. The neighbor-joining method: a new method for reconstructing phylogenetic trees. Mol Biol Evol 4:406-25.

Sjamsuridzal W, Oetari A. 2003. Rapid preparation of fungal and bacterial genomic DNA for PCR. Hayati 10:122-4.

Thompson JD, Gibson TJ, Plewniak F, Jeanmougin F, Higgins DG. 1997. The Clustal X windows interface: flexible strategies for multiple sequence alignment aided by quality analysis tools. Nucleic Acids Research 24:4876-82.

Tiirola M, Valtonen ET, Kinnunen PR, Kulomaa MS. 2002. Diagnosis of flavobacteriosis by direct amplification of rRNA genes. Dis Aqua Org 51:93-100.

Verschuere L, Rombaut G, Sorgeloos P, Verstraete W. 2000. Probiotic bacteria as biological control agents in aquaculture. Microbiol Mol Biol Rev 64:655-71. 